\title{
Finding a Place for the Victims: The Problem in Writing the History of the Cultural Revolution
}

\section{Youqin Wang}

\section{(2) OpenEdition}

\section{Journals}

Édition électronique

URL : http://journals.openedition.org/chinaperspectives/2593

DOI : 10.4000/chinaperspectives.2593

ISSN : 1996-4617

Éditeur

Centre d'étude français sur la Chine contemporaine

\section{Édition imprimée}

Date de publication : 15 décembre 2007

ISSN : 2070-3449

Référence électronique

Youqin Wang, "Finding a Place for the Victims: The Problem in Writing the History of the Cultural Revolution ", China Perspectives [En ligne], 2007/4 | 2007, mis en ligne le 30 décembre 2010, consulté le 10 décembre 2020. URL : http://journals.openedition.org/chinaperspectives/2593 ; DOI : https:// doi.org/10.4000/chinaperspectives.2593 


\title{
Finding a Place for
}

\section{the Victims}

The Problem in Writing the History of the Cultural Revolution

\author{
YOUQIN WANG
}

This paper argues that acknowledging individual victims had been a crucial problem in writing the history of the Cultural Revolution and represents the major division between the official history and the parallel history. The author discusses the victims in the history of the Cultural Revolution from factual, interpretational and methodological aspects.

\section{Prologue: A Blocked Web Memorial}

$\tau$ n October of 2000, I launched a website, www.chinesememorial.org, to record the names of the people who died from persecution during the Cultural Revolution. Through years of research, involving over a thousand interviews, I had compiled the stories of hundreds of victims, and placed them on the website. By clicking on the alphabetically-listed names, a user could access a victim's personal information, such as age, job, date and location of death, and details about how he/she was murdered or committed suicide after being tortured and humiliated.

The web memorial reached many Internet readers in China, and I was soon receiving several emails every week, even though Chinese people had much less Internet access then than they do today. Most readers saw this as a very valuable project and some offered me help. However, in March 2002, seventeen months after the Web site was launched, Beijing authorities blocked it, and readers in China cannot visit it anymore.

Why did the Chinese government block a web memorial that contains nothing but the names and life stories of victims? What harm do the authorities find in such information after the Chinese government announced the rehabilitation of all of these victims as long ago as 1979? How much distortion has historical writing on the Cultural Revolution suffered through lack of a record of the victims? The blocking of the website raised questions that had been on my mind for years before I was invited to contribute a paper on the topic "official history and parallel history" of the Cultural Revolution.

In this paper I will argue that acknowledging individual victims has been a crucial problem in writing the history of the Cultural Revolution and represents the major division between the official history that the Chinese government has allowed to be published and the parallel history that cannot pass the censorship on publications in China. As of today, no published scholarly papers have analyzed the difference between the two resulting branches in historical writings on the Cultural Revolution. Given that the authorities who control China's Internet and media have demonstrated their "sensitivity" and have resorted to silencing the voice of the victims, comparative research on the issue is required. I will discuss the victims in the history of the Cultural Revolution from factual, interpretational, and methodological aspects. The discussion is based on the documents and interviews I have collected on the Cultural Revolution over the last 20 years, and on how the history of the Revolution has been written during this time.

\section{Facts: The Forgotten Victims of the Cultural Revolution}

\section{Naming Ordinary Victims}

A huge number of people died from persecution during the Cultural Revolution. Most victims died at their work units rather than in remote concentration camps. They were attacked at so-called "mass struggle sessions" and murdered 
He Dinghua, retired elementary school teacher

killed at her home in Beijing by the Red Guards on August 27, 1966.

under the so-called "dictatorship of the masses" advocated by Mao Zedong. ${ }^{(1)}$ The murders were never a secret, but rather were used to terrify the public into submission. Indeed, widespread knowledge of this ruthless oppression was one of the major reasons why so few people openly resisted the Cultural Revolution.

Two years after Mao Zedong's death, the Chinese regime began rehabilitating victims of the Cultural Revolution and paid the families of each 420 Yuan (approximately half a year's salary on average at that time) in compensation. Nevertheless, the new leaders did not publicize the names of the victims, and did not give ordinary researchers access to the statistics and archives that the "political work division" of each work unit was required to keep on individual employees. In addition, the authorities strictly controlled the official press (there is no non-official press in China), prohibiting publication of books or articles on the Cultural Revolution. For example, Beijing-based Dongfang (East) Magazine compiled a collection of articles on the $30^{\text {th }}$ anniversary of the Cultural Revolution for its May 1996 issue. Yet, not long before the printer finished the binding, an order came that the issue should be destroyed, and a new issue without the controversial articles should be produced. Although the editors followed the order, the magazine was still shut down permanently shortly thereafter. Many authors abandoned the subject of the Cultural Revolution after finding out that investigating and publishing, although not impossible, was extremely difficult.

After the web memorial was blocked in 2002, I continued to develop the website and add more content. In 2004, I published a 570-page book in Chinese entitled Victims of the Cultural Revolution: An Investigative Account of Persecution, Imprisonment and Murder in Hong Kong. ${ }^{(2)}$ In the book, I reveal details of the tragic stories of 659 victims: when, where, and how they died. The victims include teachers, writers, doctors, farmers, factory workers, low and highranking cadres, and aged housewives. It was the first book on the victims of the Cultural Revolution based on first-hand investigation.

In the Foreword ${ }^{(3)}$ to the book, Professor Roderick MacFarquhar wrote:

In this book, Professor Wang takes a very important step in the direction of making her fellow Chinese confront their recent past. With painstaking efforts, and doubtless much frustration and many impediments, she has lifted the veil on the violence, particu- larly in two periods which she considers the worst of the Cultural Revolution, the Red Guard summer of 1966, and the "cleansing of the class ranks" by revolutionary committees during the winter of 1968. She does this by recounting, one by one, the fates of many hundreds of victims, thus ensuring that they will not be forgotten.

More than 90 percent of the 659 victims named in my book died during these two major yundong (movements) of the Cultural Revolution, which consisted of countless acts of cruel persecution conducted nationwide under clear and detailed instructions from Mao Zedong.

Apart from the alphabetical name index, my book also provides an index of the locations of the killings. Although I identified only a few hundred names, the available information indicates how high the percentage of victims in the general population might have been. For example, ten teachers and staff members out of a total of 116 employees of the Girls' Middle School Attached to Beijing Teachers University died from persecution, along with one outsider who was beaten to death on the campus. ${ }^{(4)}$ At the Beijing Third Girls' Middle School, the principal and four teachers died from persecution, along with two outsiders killed on campus and seven spouses of employees. ${ }^{(5)}$ Two teachers out of 30 employees were victimized at Mataxiang Middle School in rural Jingyan County, Sichuan Province. ${ }^{(6)}$ Sixty-three victims died at Peking University, ${ }^{(7)}$ and 58 at Tsinghua University. ${ }^{(8)}$ In addition, my investigations found violent persecution at every workplace examined, without exception. ${ }^{(9)}$ The number of victims a single researcher can identify is in-

1. Mao Zedong, July 9, 1967. It is an idea Mao emphasized for many years

2. Wenge shounanzhe: guanyu pohai jianjin he shalu de xunfang shilu (Victims of the Cultural Revolution: An Investigative Account of Persecution, Imprisonment and Murder), Hong Kong, Open Press, 2004.

3. The Foreword was written in English, which I translated into Chinese for publication in the book. This quote is from the original English version.

4. Wang Youqin, "1966: Xuesheng da laoshi de geming" (1966: The Revolution of Students persecuting Teachers), Twenty-First Century, $n^{\circ} 4,1995$. The paper has been updated many times, and the latest version can be accessed on my website.

5. Chen Shouren, "Beijing nü san zhong de sha ren jilu" (Beijing Third Girls Middle School Killing Records), Open Magazine, May 2007.

6. See Wenge shounanzhe, op. cit., p. 234, 496

7. Wang Youqin, "63 Victims and the Cultural Revolution at Peking University," Twenty-First Century, $n^{\circ} 2,2006$.

8. Tao Shaojie, "Unnatural Deaths at Tsinghua University during the Cultural Revolution," Twenty-First Century, n² 2, 2006

9. See Wang Youqin, Wenge shounanzhe, op. cit.. 
evitably limited. Yet, if the proportion of the victims I found is applied throughout China's working population at the time, the total number of victims can be estimated to be in the millions.

Most of the victims identified in my book were never reported by name in official media either during or after the Revolution. In 1999, a book published in Hong Kong to mark the $50^{\text {th }}$ anniversary of the People's Republic of China listed the names of victims of the Cultural Revolution that the editor had compiled from books and essays published in China between 1978 and 1999. ${ }^{(10)}$ Although it represents a fairly comprehensive search of the published written sources during those 23 years, it includes only 69 names, all of them high-ranking cadres or celebrities. This number is just slightly higher than the number of victims I identified in one school, Peking University, where 63 victims died of persecution.

During the Cultural Revolution, China's newspapers and magazines did not publish a word concerning the ongoing violence and murder while reporting daily and with banner headlines on the nation-wide activities of the revolution's driving forces such as the Red Guards and the Revolutionary Rebels. Images in newspapers, magazines, and documentary films published by the Chinese authorities at that time depicted millions of teenagers wearing Red Guard armbands while marching through Tiananmen Square, and Mao Zedong shaking hands with their leaders atop Tiananmen Gate. Against the background of the red walls of the Gate, Mao's little red books, red flags, and red slogans, the young, jubilant Red Guards created the widely-publicized iconic image of the Revolution. The media did not report the bloody side of the Revolution, in which many teachers and people in the categories of "class enemies," as well as students from the so-called "black five kinds" of families, were physically attacked, injured, and even beaten to death by the Red Guard students. (II) Another death that went unreported during the Cultural Revolution was that of President Liu Shaogi, who died in 1969 after three years' imprisonment and torture, but whose death was not revealed to the Chinese people until 1980, when the new leaders of the Party decided to rehabilitate him.

Not only were the stories of violence not reported at the time of their occurrence, they were not reported until after the Revolution ended with the death of Mao Zedong and a new regime took over. It was only in 1978-79, after the death of Mao Zedong led to the termination and repudiation of the Cultural Revolution by the Party's inner circle, that the Chinese media cautiously began mentioning some high-ranking or famous victims as a means of restoring their reputations. The articles revealed little about how the victims were persecuted or murdered. They were simply described as "good comrades," "loyal to the Party," who had been persecuted by the "Lin Biao clique" and the "Gang of Four." By an unwritten rule, only victims of the vice ministerial rank or higher were acknowledged in national-level newspapers.

\section{Official history: partial and selective accounts}

After the new Chinese authorities repudiated the Cultural Revolution, three books providing a general history of the Cultural Revolution were "officially" published in 1986, 1988, and 1993. All three books portray the Cultural Revolution as a negative event, but none of them provides details of the brutality suffered by ordinary people.

Wenhua da geming shinian shi ${ }^{(12)}$ (History of Ten Years of the Cultural Revolution) by Gao Gao and Yan Jiagi was the first book of general history of the Cultural Revolution. In fact, this book cannot be considered "published." Before the book was sent to bookstores, complaints by Tan Lifu, head of the Red Guards of Beijing Industrial University, led Party Secretary Hu Yaobang to suppress distribution "in order to maintain stability and unity" in October 1986. The publishing house, which had reportedly already printed 600,000 copies of the book by then, faced a huge financial loss. (Later the book was approved for neibu (internal) sale through specified government offices, but the ban on general distribution has never been lifted.) Three months later, on 7 January 1987, Hu Yaobang resigned, just as Khrushchev had in 1964, two years after approving the publication of Aleksandr Solzhenitsyn's work. The authors Gao and Yan are a married couple, and Yan was the head of the Institute of Political Science under the Chinese Academy of Social Sciences. They fled China in 1989 after the Tiananmen Massacre. In the spring of 2007, a young reader in China

10. Jin Zhong (ed), Gongchan zhongguo wushi nian, (Fifty Years of Communist China: 19491999)," Hong Kong, Open Press, 1999, pp. 229-231.

11. See my three articles, (1) in note 3; (2) "Terrorizing Classmates during the 'Red August' of 1966: Cultural Revolution Facts and Analysis," Chinese Studies, n 2, 1996; (3) "Between the Persecution of Teachers and the Persecution of Fellow Students," Twenty-First Century, $n^{\circ} 5,1996$.

12. Gao Gao, Yan Jiaqi, Wenhua da geming shinian shi, Tianjin, Tianjin renmin chubanshe, 1986. 
told me in an email that he had just bought a low-quality pirated copy of this book for 10 Yuan.

Gao and Yan's book is the only one of the three that mentioned the names of ordinary victims of the Cultural Revolution. The book refers to the deaths of $\mathrm{Xu}$ Peitian, a retired janitor, and Wang Guanghua, a student, in its chapter on the rise of the Red Guard movement. ${ }^{(1)} \mathrm{Xu}$ and Wang were both beaten to death in a campus jail that the Red Guards established in the music classroom of Beijing Sixth Middle School, which was located across the street from the headquarters of the Chinese Communist Party and just a few hundred meters from Tiananmen Square. Xu was falsely accused of being the owner of a vehicle repair shop before 1949. Wang Guanghua was not allowed to join the Red Guards because his family owned a small business before 1949, but disobeyed the order of the Red Guards and attended the "revolutionary networking" (chuanlian) in the provinces. In fact, a third person was also killed in that campus jail, but since He Hancheng, ${ }^{(14)}$ an old man who owned several houses for rent near the school, was an actual "capitalist," his death was not mentioned in the book.

The second book, Da dongluan de niandai (The Turbulent Years), ${ }^{(15)}$ by Wang Nianyi, was published in 1988 and has been available in state-owned bookstores since then, with several reprints and a newly revised edition published in 2005. This book does not mention any victims of the Red Guard violence of 1966, claiming that the most serious violence was some teachers having their heads half shaved. ${ }^{(16)}$ In a subsequent paper, I pointed out the serious omissions in Wang $\mathrm{Ni}$ anyi's description and documented 11 educators who were beaten to death by the Red Guards. ${ }^{(17)}$ In the updated English version published in 2001, ${ }^{(18)}$ I listed 30 names of educators who were murdered, and more who committed suicide after being tortured and humiliated. Wang Nianyi did not respond and did not make any relevant changes in the new 2005 edition. While allocating two pages to defending the Red Guard violence in August 1966, Wang limits acknowledgement of the victims to a single sentence that literally reads: "According to statistics, in August and September 1966, Beijing City beat more than 1,000 people to death." ${ }^{(19)}$ The grammatically clumsy sentence, which lacks a subject for the verb "beat," deliberately avoids mentioning the perpetrators who did the killing. In fact, the official number of people killed by the Red Guards in Beijing was 1,772, a number acknowledged in the third book officially published on the Cultural Revolution by Jin Chunming.

In addition, the number 1,772 is quoted in a casual and diminishing way as "more than 1,000 ." Both authors were af-
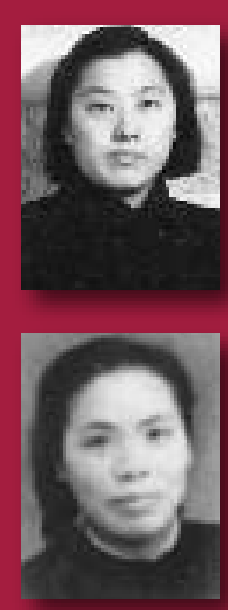

Sun Lisheng, teacher of Beijing Third Girls School, died on campus on July 12, 1968.

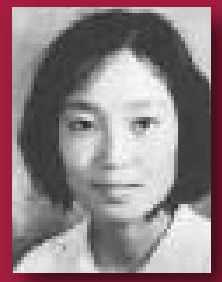

Hu Xiuzheng, teacher of Girls Middle School attached to Beijing Teachers University, died on campus on August 11, 1968.

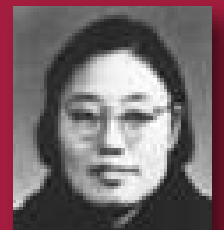

filiated with China's most authoritarian institutes-the Central Party School (Jin Chunming) and The National Defense University (Wang Nianyi)-and had access to data from the Party's internal documents. Both books mention the number in a single sentence without further comment. Neither of the two authors asks who was killed or who killed the victims, as if the murder of 1,772 people required no elaboration.

Jin Chunming's book, Wenhua geming shigao (A Draft History of the Cultural Revolution), ${ }^{(20)}$ like the first and second books, is mostly devoted to describing events that had been reported in the Chinese media during the Revolution and reversing the previous verdicts. For example, the case of Liu Shaogi, who was accused during the Cultural Revolution of being the "number one capitalist roader in the Party," is high-

13. Gao Gao, Yan Jiaqi, ibid., p.75.

14. The three victims' stories were included on the web site www.chinese-memorial.org and in the book Wenge shounanzhe.

15. Wang Nianyi, Da dongluan de niandai, Zhengzhou, Henan renmin chubanshe, 1988 reprinted in 1992, 2004

16. Wang Nianyi, ibid., p. 86

17. See ibid.

18. "Student Attacks Against Teacher: The Revolution of 1966" (revised version), Issues and Studies, $n^{\circ} 2$, April 2001.

19. Wang Nianyi, op. cit., p. 69.

20. Jin Chunming, Wenhua geming shigao (A draft history of the Cultural Revolution), Chengdu, Sichuan renmin chubanshe, 1995, p. 521 
lighted in Jin's book as the "number one unjust case." The author attributes Liu Shaogi's death to fraudulent testimonies that convinced Mao Zedong that Liu was a "traitor," as if Mao were a naive child. ${ }^{(21)}$ The book makes no mention of the "Cleansing the Class Ranks," the Mao-instigated "movement" that killed more than half of the victims of the Cultural Revolution and subjected countless others to physical and mental abuse. Wang Nianyi's book devotes two of its 644 pages to this "movement," but names none of its victims. In 1999, a two-volume, 1,555-page book entitled Wenge dang'an (The Cultural Revolution Archive) was published as the third volume of Huihuang 50 nian: gongheguo dang' an (The Glorious 50 Years: The Republic's Archive). ${ }^{(22)}$ This book, compiled by a group of authors and three times the length of the three books referred to above, makes no mention of the Red Guard killings of ordinary people in 1966, let alone citing the number of "1,772" murdered victims discussed above. A large number of chronicles have been published at the province or county levels since the late 1980s. Many colleges and middle schools have also compiled school histories. How do they deal with the ten years of the Cultural Revolution? The Annals of Beijing Xicheng District (published in 1999) ${ }^{(23)}$ lists only four deaths of middle school principals and does not mention that it was Red Guard students who killed them. By contrast, an article entitled "On the Middle and Elementary Schools in Beijing During the Cultural Revolution," published in 1991, briefly mentions that in Beijing's Xicheng District, during two weeks in August 1966 alone, nearly 100 teachers, administrators and staff died from torture, while countless others were injured or maimed. ${ }^{(24)}$ From 1991 to 2000, the murders went entirely unmentioned. In fact, besides the educators, the Red Guards killed more than 300 residents of Xicheng District in August and September of 1966.

Educators were one of the largest groups of victims, but even the school history books do not record the total number of victims. For example, 39 teachers were persecuted to death at Peking University, but the two-volume Beijing daxue jishi (1898-1997) (Peking University Chronicles) ${ }^{(25)}$ only reports the deaths of some full professors and does not mention any names of associate professors or lecturers. The two-volume Qinghua daxue zhi (Annals of Tsinghua University) ${ }^{(26)}$ lists only partial numbers of victims and provides only two names. ${ }^{(27)}$ Professor Tang Shaojie's paper entitled "Unnatural Deaths at Tsinghua University during the Cultural Revolution" and my paper "63 Victims and the Cultural Revolution at Peking University" provide more complete lists of the victims and how they died miserably at China's two most prestigious universities. However, both articles had to be published in a Hong Kong journal ${ }^{(28)}$ and could not be published in China. In 1986, the Beijing City Institute of Education printed (but did not officially publish) a series on the history of some middle schools, ${ }^{(29)}$ which briefly mentions the violence and deaths that occurred at these schools. Yet in 2000, when I called a person who worked in the "school history office" of Beijing Chenjinglun Middle School (which was not included in the series) and asked for the name of a female teacher who was killed by Red Guards on campus in late August 1966, the person replied loudly that "we just skip that period" and refused to help me. ${ }^{(30)}$ "Skipping" a certain period was taken as an unquestioned matter for this school history writer.

Pan Guangdan is one of the 659 victims in my book. He attended universities in the United States and was a famous anthropology professor in China before 1949. He was forced to carry out so-called "self-criticism" by insulting his parents and professors and classmates in 1951 and was labelled a "Rightist," a main category of "enemy," in 1957. When the Cultural Revolution started, Pan was forced to do heavy work, so-called "reform through labour," on campus in 1966 and 1967, even though he was seriously handicapped (he lost one leg when he was young) and could not walk without crutches. Just before he died in 1967, he told a friend that his life after 1949 could be summarized with four English words starting with the letter S: surrender, submit, survive, and succumb. ${ }^{(31)}$

In fact, Professor Pan's experience is rather typical of people with similar educational backgrounds and professional positions. However, in the Chinese Encyclopedia of 1991, the entry about him reads as follows:

21. Jin Chunming, ibid., pp. 265-270.

22. Li Songchen, Tang Hejian, Du Shusheng (eds), Huihuang 50 nian: gongheguo dang'an (The Glorious 50 Years: Archives of the Republic), Beijing, Dangdai Press, 1999, volume 3: Wenge dang'an (Archives of the Cultural Revolution).

23. Beijingshi Xichengqu zhi bianzhuan weiyuanhui, Beijing Xichengqu zhi, Beijing, Beijing Press, 1999, p. 32

24. Wang Jian, "Wenhua dageming shiqi Beijing pujiao zhuangkuang"; "Beijing K-12 Education during the Cultural Revolution," Beijing jiaoyu congkan, n 4, 1991.

25. Beijing daxue jishi, Beijing, Peking University Press, 1998.

26. Qinghua daxue zhi, Beijing, Tsinghua University Press, 2001.

27. Qinghua daxue zhi, ibid., volume 2, p. 758

28. Twenty-First Century, $n^{\circ}$ 2, 2006.

29. It contains: History of Beijing 26th Middle School, History of Beijing 101st Middle School, Brief History of Beijing Yucai School, History of Beijing Tong County First School, History of Beijing 166th Middle School, Middle School Attached to Qinghua University.

30. Later I found the name of the murdered teacher through other people. She was a biology teacher and her name was Qi Huiqin. She was brutally beaten to death on the campus of the girls' middle school. See Wenge shounanzhe, op. cit., p. 328.

31. See Wenhe shounanzhe, op. cit., note 2, p. 314-326. 


\begin{abstract}
Pan Guangdan, 1899-1967
Born in 1899 in Jiangsu Province, Baoshan County, Luodian Town. 1912-1922: preparatory study at Beijing Qinghai School for study in the United States. 1922-1926: studied in the United States. First studied biology at Dartmouth College, New Hampshire, received a Bachelor's degree, then studied zoology, palaeontology, and genetics at Columbia University and received a Master's degree. In 1926 he returned to China and worked as professor at Shanghai Daxia University, Fudan University, and Guanghua University. After 1934, he worked as professor at Tsinghua University, dean, chair of sociology department. Later, he was professor and chair of department of sociology of Northwestern United University. 1952-1967: worked in Central Nationalities College, as chair of third division, served as a member of the second, third, and fourth "Chinese People's Political Consultative Conference." Died on 10 June 1967. ${ }^{(32)}$
\end{abstract}

From the entry above, one cannot see much difference between Professor Pan Guangdan's life and that of professors who lived their entire lives elsewhere in the world. Nothing in the entry is false, but it has omitted two important facts: Pan was labeled a "Rightist" in 1957, and he died from torture during the Cultural Revolution. Pan Guangdan's encyclopaedia entry suggests that the Anti-Rightist Movement, the Cultural Revolution, and all other persecution movements never occurred. Biographies like Pan's are common, but are they truthful? This methodology of selective factual reporting has become the major characteristic of the official history of the ten years of the Cultural Revolution.

Given the absence of names of ordinary victims and their sufferings in official history, people in China have told me that they are not surprised that the web memorial has been blocked for more than five years. Although the victims on the website all received a piece of paper offering them "rehabilitation" (pingfan), their names and stories are still taboo both in print and on the Internet.

\section{Interpretation: Errors or Crimes}

Inevitably, any historical narrative is related not only to facts but also to the interpretation of those facts, especially in the case of recent historical events such as the Cultural Revolution. For historians, facts should be the priority at all times, and interpretation should derive from facts. In the case of the official history of the Cultural Revolution, however, we can see that the way Chinese authorities have interpreted the Revolution has affected the way historians select the facts. In the Foreword to Victims of the Cultural Revolution, Professor Roderick MacFarquhar points out:

In the case of the Cultural Revolution, the CCP has
grappled with the need for a reckoning in its 1981
Resolution on Party history. The Resolution blamed
Mao Zedong, "a leader labouring under a misappre-
hension," for initiating and leading the Cultural Rev-
olution, but described the actions of the Gang of Four
and Lin Biao as "of an entirely different nature...
[they took] advantage of Comrade Mao Zedong's er-
rors, committed many crimes behind his back, bring-
ing disaster to the country and the people"; they in-
cited people to "overthrow everything and wage full-
scale civil war.

Starting in 1978, Deng Xiaoping and Hu Yaobang rehabilitated millions of people who were victims of the Cultural Revolution and even earlier persecutions such as the "AntiRightist Movement" (1957) and the "Suppressing Counterrevolutionaries Movement" (1950-1952). They also removed all charges against those who survived, and released those who had been imprisoned as "counterrevolutionary elements." This is one of the most significant changes that occurred after Mao's death. The countless families of victims were grateful for the new policies, which many might not have expected. If Mao Zedong had not died in 1976, the rehabilitation would not have happened. However, Deng and Hu simply referred to their actions as "reversing cases of injustice," and the new government laid the blame on Lin Biao and the "Gang of Four" rather than on Mao Zedong. They insisted that Mao Zedong made only "errors," but that Lin Biao and the Gang of Four committed "crimes." Official history selected the facts that conformed to the 1981 "Resolution" of the Party, and avoided facts that could not be explained with the Party's interpretations.

The so-called Gang of Four included Mao's wife Jiang Qing and three other men who were promoted into the central circle of leadership from much lower ranks during the Cultural Revolution. Before Jiang Qing became Mao's wife in the 1930s, she was a movie actress in Shanghai and had been previously married. Fearing that her history threatened her ability to rise in the Party, Jiang ordered the destruction of

32. Chinese Encyclopedia, Beijing, Encyclopedia Press, 1991,Volume of Sociology, p. 213. 
documents pertaining to her from that period and the imprisonment of those who had worked with her. Her persecution of movie directors and actors was detailed in her 1981 trial and later in official media, and Gao and Yan's book devotes 12 pages to reporting these stories. ${ }^{(33)}$

On 26 July 1966, Jiang Qing gave a speech at Peking University to more than 10,000 people, praising violent actions on 18 June against the "class enemies" on Peking University's campus. Her speech encouraged violence to spread quickly. On 5 August, Bian Zhongyun, vice principal of the Girls' Middle School Attached to Beijing Teachers University, was beaten to death and became the first victim killed by Red Guards.

Jiang Qing met the leaders of Red Guards of middle schools several times and called them "little suns." On 18 August, at the rally of one million Red Guards in Tiananmen Square, Song Binbin, head of the Red Guards in Bian Zhongyun's school, presented a Red Guard armband to Mao, and Mao commented on her name, which means "elegance," by remarking, "Be violent!" Killing escalated immediately after the rally, with thousands of teachers and residents killed in two weeks in Beijing. Red Guards also raided people's homes and drove out 100,000 residents, about two percent of the city's population, accused of belonging to "enemy" categories. ${ }^{\left({ }^{44)}\right.}$ Similar bloody events occurred in other provinces during that period.

China has a long history of respecting education. The killing of teachers by students on a large scale had never happened in the past. The murders of thousands of teachers and Beijing residents were no less serious crimes than the persecution of actors and actresses who had known Jiang Qing in the 1930s, but the Red Guard killings in August 1966 were not counted as major crimes either at Jiang Qing's trial or in the published histories of the Cultural Revolution. The murder of the middle school principal Bian Zhongyun was not mentioned in any publication prior to an article I published in 1988, not only because she lacked the privilege of being a high-ranking cadre, but more importantly because she represented a large group of victims of a far more serious crime. The persecution of the actors who knew Jiang Qing in the 1930s can be reasonably attributed to Jiang Qing's personal motivations. But the murders of teachers and residents cannot be interpreted in this way and have to be attributed to Mao Zedong's leadership, and its bloody nature is evidence of a genocidal crime. This is the main reason why the most bloody and characteristic aspects of the Cultural Revolution were simply deleted from the trial of the "Gang of Four" and from history books.
The interpretation that attributes the disaster of the $\mathrm{Cul}$ tural Revolution to Lin Biao and the Gang of Four in their efforts to seize control of the Party is too weak to adequately explain the origins of the Cultural Revolution, especially the cruel persecution of millions of ordinary people. In the early 1980s, Wang Ruoshui (1926-2002), a Marxist theorist of the Party, advanced a new theory of "alienation" to explain the origin of the Cultural Revolution. According to his theory, what caused the tragedy was the "alienation" of socialism from humanism (not socialism itself). In addition, he argued that humanism should be an important part of Marxism (in Mao's time humanism was referred to negatively as "bourgeois humanism"), and he advocated criticizing the Cultural Revolution from the standpoint of humanism. Wang Ruoshui tried hard to confront and interpret the cruel persecutions of the Cultural Revolution rather than just blame Lin Biao and the "Gang of Four," while at the same time trying not to defame socialism or Marxism. The top Party leaders disapproved of Wang Ruoshui's theory, and he was demoted from his position as deputy chief editor of People's Daily during the campaigns against "bourgeois liberalization" and "spiritual pollution" in 1983. In fact, few Chinese, even among the well-educated, understood Wang Ruoshui jargon-laden and ambiguous language when the Party Central mobilized them to study its new directive against the "alienation" theory. ${ }^{(35)}$ The official attack on this theory resulted in the erasing of the victims and the antihuman persecutions from public memory so that no theory would be needed to interpret them. ${ }^{(36)}$ In reality, where there is a tyrant there are victims. The process of historical writing may be reversed; victims documented in historical writings make the perpetrator who murdered them a tyrant. Without the large number of victims, the 1981 Party Resolution can get away with describing the Cultural Revolution as Mao Zedong's error instead of his crime.

On the one hand, those working to produce the official history select facts in accordance with the Party's interpretation, which then provide the basis for a new interpretation. For instance, on August 30, 1966, during the peak of the Red Guard killings, Premier Zhou Enlai wrote a note on

33. Gao Gao and Yan Jiaqi, op. cit., p. 417-428.

34. See Wang Youqin, "Student Attacks Against Teachers: The Revolution of 1966," art. cit.

35. 1983 №. 36, 24 October, 1983

36. See Wang Ruoshui's book Wei rendaozhuyi bianhu (Defense of Humanism), Beijing, Renmin chubanshe, 1986 
paper with pencil listing 13 names of people who were all "United Front elements" (Tong zhan duixiang), including Song Qingling, vice president of the People's Republic of China and widow of Sun Yat-sen. Zhou ordered that the homes of these 13 people be protected from the Red Guards. In official publications after the Cultural Revolution, Zhou's note is interpreted as strong and palpable evidence of his efforts to stop wrongdoing during the Cultural Revolution, ${ }^{(37)}$ but this interpretation is only tenable in a context in which the victims among teachers and residents are deleted from history. The fact is that when Zhou wrote the note, hundreds of ordinary people were being killed daily by Red Guards in Beijing alone. Writing a note that protected only 13 individuals actually served as tacit consent to the mass killings. ${ }^{(38)}$

According to those who have had a chance to examine "internal documents," the actual number of deaths was reported to the central authorities every day through several information collecting offices. If the number of killings had been published, it would have been difficult to maintain Zhou Enlai's positive image, which the Party tried very hard to preserve after the Cultural Revolution. Zhou's image helped the government to describe the Cultural Revolution as a "most severe setback and the heaviest losses suffered by the [Chinese Communist] Party, the state, and the people" (1981 Resolution), as if the Party were the major victim rather than the people.

Books by former active cultural revolutionaries also ignore the victims. In 2004, two memoirs on the Cultural Revolution by $\mathrm{Xu}$ Jingxian and Nie Yuanzi were published in Hong Kong. ${ }^{(39)}$ Both $\mathrm{Xu}$ and Nie were very famous and occupied high and influential positions during the Revolution. $\mathrm{Xu}_{\mathrm{u}}$ was the third most important person in the Shanghai Revolutionary Committee (the two men above him were members of the Gang of Four) for ten years and was sentenced to 18 years in prison after the Cultural Revolution; $\mathrm{Nie}$ was the head of the Cultural Revolution Committee of Peking University. According to "internal statistics," 11,150 people were persecuted to death in Shanghai, but Xu Jingxian mentions none of their names in his 433-page book. Likewise Nie Yuanzi complains about her 17-year prison sentence but makes no apology regarding the 63 people who died at Peking University. Both $\mathrm{Xu}$ and Nie are clever enough to know that there are no perpetrators without victims, so they simply deny the existence of the victims. Chinese authorities did not approve the publication of these books, but share the authors' treatment of the issue of victims.

The government's suppression of the facts regarding victims eventually facilitated denial of the criminal history of the
Cultural Revolution. After Nie Yuanzi published her book, her medical privileges as a high-ranking cadre, eliminated at the time of her criminal conviction, were restored. When she appeared at the special clinic of the Third Hospital affiliated to Peking University, old doctors there were surprised, while young people there had no idea who she was. On 9 September 2007, Song Binbin, the iconic figure of the Red Guards, was named "outstanding alumna" at a gathering in the Great Hall of the People marking the 90th anniversary of the Middle School Attached to Beijing Teachers University (which was a girls' school before the Cultural Revolution). The well-known photo showing Song presenting the Red Guard armband to Mao Zedong on 18 August 1966 was exhibited on campus and printed in the book commemorating the school's anniversary. The fact that Red Guards had beaten Vice-Principal Bian Zhongyun to death 13 days before the photo was taken, and that thousands of Beijing residents had been killed subsequently, went completely unmentioned.

Western scholars biased in favour of the Cultural Revolution have also shown reluctance to acknowledge or face up to the incidents of violence and the large number of victims, which have been reported to a certain extent in Chinese and in other languages such as English and Japanese. In 2005, in a 32page article entitled "The Cultural Revolution: The Last Revolution?" ${ }^{(40)}$ a French professor, Alain Badiou, praised the Cultural Revolution with phrases such as "a great exchange of experience" and "a struggle against revisionism." The article narrated the whole process of the Revolution, and mentioned the names of Mao Zedong, Zhou Enlai, and even Kuai Dafu, a "rebel" student leader in 1966-68, but made no mention of the victims. It is difficult to judge whether Badiou pretended to know nothing of the facts, or whether he simply did not care how many people were murdered. He did not even bother to make a serious defence of the Red Guard violence, but merely interpreted it with one sentence:

37. Zhou Enlai, Zhou Enlai xuanji, Beijing: Renmin chubanshe, 2000, volume II, p. 450-451 Zhou's handwriting can be seen in Wenhuadageming zhong de Zhou Enlai (Zhou Enlai in the Cultural Revolution), as a part of the documentary film entitled Maozedong yu zhongguo (Mao Zedong and China), Huanan and Jiangxi Video Press, ISBN 7-88504491-2.

38. See the chart of daily deaths from 24 August to 7 September, 1966 in Victims of the Cultural Revolution, p. 224. From 26 August to 1 September, the number of daily killing was in the triple digits. The killing peak occurred on 1 September, when 282 people were killed.

39. Xu Jingxian, Shi nian yi meng (Ten Years as a Dream), Hong Kong, Shidai Guoji Press 2004; Nie Yuanzi, Nie Yuanzi huiyilu (Memoir of Nie Yuanzi), Hong Kong, Shidai Guoji Press, 2004

40. Positions, vol. 13, $\mathrm{n}^{\circ}$ 3, Winter 2005. [Alain Badiou, La Révolution culturelle : la dernière revolution?, Paris, Le Perroquet, 2002, 34 p.] 
... what made the barbarism of certain revolutionary shock groups considerably worse was the fact that there was never, on the scale of youth action, a global political space for political affirmation, for the positive creation of the new.

As in courts of law, the principle of telling the "whole truth" and "nothing but the truth" is fundamental in historical writing. Without reports about the gas chambers or victims such as Anne Frank, Hitler and the Third Reich would simply be described as a bellicose episode that was hardly unique in European history. Without the account of the Gulag Archipelago, Stalin's regime would look similar to that of a typical Tsarist ruler in Russian history. Reviewing the historical writing of the Cultural Revolution over the last 30 years, we can see that both principles are important for historical writing, but that the "whole truth" is more significant than "nothing but the truth." When a portion of the facts about victims is covered up, the larger picture is distorted, and the nature of the Cultural Revolution is misinterpreted.

\section{Method: Investigation or Restriction to second-Hand Sources}

The "parallel history," in contrast with the official history of the Cultural Revolution, has not been very developed over the last 30 years. The main reason is that the Beijing authorities have continuously issued orders and adopted measures to prevent publications from deviating from the course the Party set. This paper will not discuss the role of the government in historical writing, however, but will simply focus on the writing itself. I would like to point out that in addition to official control and censorship, one reason why the authors of the three books of general history on the Cultural Revolution neglected the subject of victims is that they relied mainly on published materials and did little investigation on their own. For instance, Gao Gao, one author of these histories, writes in the preface that the book relies on three kinds of sources: publications of the government and "revolutionary organizations" such as the Red Guards during the Cultural Revolution, and official publications after the Cultural Revolution. ${ }^{(4)}$

As noted earlier, publications during the Cultural Revolution were under very strict censorship and did not report victims' stories. After the Revolution, the media reported only on famous and high-ranking victims because the authorities did not want full disclosure of the crimes committed during the
Revolution. With the Chinese media openly identifying themselves as the "Party's propaganda tools," historical writing based purely on such materials cannot possibly be expected to meet academic standards.

More recently, new technology has made it possible for nonofficial Chinese historians to make their voices heard. They can post essays on the Internet and reach hundreds of thousands of readers, or use digital cameras to make films that would have been completely beyond the reach of ordinary Chinese just a few years ago. This alternative voice is still very weak, but is growing stronger and is gradually creating a non-official history, or a "real history." China's 2,500-year historical writings started with characters drawn on bamboo slips. We have reason to hope that people can accomplish more on the subject of recent history in the computer age. In this context, two documentary films by $\mathrm{Hu}$ Jie (1958-, living in Nanjing), Seeking the Soul of Lin Zhao and Though I Am Gone, are outstanding works worthy of attention. The two films, produced from the modest salary of Hu's wife Jiang Fenfen, have not been screened in China, but VCDs of the films have been circulating among ordinary people for years, and Though I Am Gone has been posted on Youtube since April 2007. These films reveal not only history, but also the filmmaker's efforts to retrieve the real past, which is a major reason why the two films in their simple style have deeply touched so many viewers.

In Seeking the Soul of Lin Zhao (2004), Hu Jie travels through several provinces and interviews many people who had met Lin Zhao (1932-1968) during the years from 1950 to 1968 . They told stories about this idealistic young girl who had followed the Party in the early 1950s until she showed sympathy for classmates who were being attacked and labelled as "Rightists" in 1957. Labelled a "Rightist" herself, she was sentenced to 20 years' imprisonment for political poems she wrote in the early 1960s. After criticizing Mao Zedong in the diary and poems she wrote in prison in Shanghai, she was sentenced to death on 29 April 1968 and executed immediately. (In fact, $\mathrm{Xu}$ Jingxian, mentioned above, was one of those who signed the death sentence.) After she was executed, police went to Lin's mother and charged her for the bullet that had killed her daughter. Besides on-camera interviews, Hu Jie shows many original documents in the film, including court records and Lin Zhao's manuscripts.

In 1979, People's Daily reported on the case of a female Communist Party member named Zhang Zhixin (1930-

41. Gao Gao, Yan Jiaqi, op. cit., preface, p. 2. 
1975) ${ }^{(42)}$ who was executed for her "counterrevolutionary speech" during the Cultural Revolution. Nevertheless, People's Daily emphasized that she had been given the death penalty unfairly because she opposed Lin Biao and the Gang of Four, and that she had been condemned by the Gang of Four and their agents in her province. People's Daily avoided mentioning whether Zhang Zhixin had criticized Mao Zedong. They shaped the image of Zhang Zhixin as a martyr according to their needs-repudiating the Cultural Revolution but not Mao-in spite of the fact that Mao was inseparable from the crimes of the Cultural Revolution and the Gang of Four. In contrast with the official report on Zhang Zhixin, Hu Jie's film on Lin Zhao pursues the whole truth and draws a realistic image of a victimized heroine.

Though I Am Gone (2006) reports on the murder of Bian Zhongyun, the high school vice-principal mentioned above who was killed by her Red Guard students on 5 August 1966. The film shows Bian's bloodstained clothes and her broken watch, which stopped around the time she was beaten to death. Bian Zhongyun's husband Wang Jingyao has kept this evidence for 40 years, and finally was able to display it publicly as testimony to the brutality of the Red Guards and the Cultural Revolution. Wang Jingyao also provided photos of this evidence to Carma Hinton, the American producer of the film Morning Sun (2004, Long Bow Company), but Hinton did not use the photos and returned them to him. Watching Hinton's film makes the reason clear: showing this evidence would make it impossible to maintain the film's positive image of the Red Guards as the "morning sun." Former Red Guards from five middle schools in Beijing appeared in Hinton's film, and not one of them apologized for what the Red Guards did in 1966 in those five schools, whereas in 2000 I had already documented the names of eight victims on the Internet. ${ }^{(43)}$

Morning Sun was produced in four languages and has appeared on public television stations in the United States, the United Kingdom, Germany and France. Though I Am Gone is available only in Chinese with English subtitles produced by a volunteer translator, and people in China cannot access the film on Youtube. Without any financial support, $\mathrm{Hu}$ Jie has persisted in producing films that cannot be freely viewed in his own country. All the same, his lonely voice has been acknowledged by the praise of his fellow citizens. To a certain extent, Hu Jie's situation echoes that of writers who continue to produce their unofficial history of the Cultural Revolution.
As a conclusion, it is worth mentioning the story of the two versions of China's 100 Yuan notes. One was issued for the first time in 1980, just after the Party restored Liu Shaogi's reputation, and his portrait is printed on the bill along with that of Mao Zedong, Zhou Enlai, and Zhu De. The close arrangement of the four portraits gives no hint of the bloodsoaked turmoil of the Cultural Revolution, or of the three years of torture that led to Liu's death. Nearly 20 years later, in 1999, a new version of the 100-yuan bill was issued, and has remained in circulation since then. The new bill no longer depicts four men, but only one - Mao Zedong. The younger generation does not know who Liu Shaogi was, or what happened during the Cultural Revolution; Liu and the other "secondary players" of that period were simply removed from the bill. There is an old Chinese saying: "It is possible to change a big event into a small event, and a small event into nothing at all." Is this the inevitable fate of the true history of the Cultural Revolution and its victims? My hope is that the story of the 100-yuan bills does not become a symbol for the history of the Cultural Revolution. •
42. "Fighting for the Truth: Story of the Outstanding Communist Party Member Zhang Zhixin Opposing Lin Biao and the Gang of Four, People's Daily, 25 May 1979. Several follow-up essays were published later.

43. The five middle schools are the Attached Girls' Middle School of Beijing Normal University, Beijing 101 Middle School, the Tenth Girls' Middle School, Middle School attached to Tsinghua University, and Middle School Attached to Peking University. Red Guards murdered people at all five schools in 1966. I have reported nine victims on my Web site and in my written publications (eight in 2000 and one in 2005). Their names are Bian Zhongyun, Chen Baokun, Sun Di, Liu Shuhua, Guo Lanhui, Wu Suzhen, and Chen Yanrong. After the Red Guards of the Attached Girls' Middle School at Beijing Normal University murdered Bian Zhongyun, they beat an 18-year-old waitress of the Yuhuatai restaurant near the school, but I have not been able to find out the girl's name. The Red Guards of the Middle School of Peking University also killed an old woman when they murdered Chen Yanrong on 27 August 1966. The nine victims are only those I have been able to identify; the total number of people murdered by Red Guards at those five middle schools remains unknown. 